\title{
Numerical investigation of optimized piled raft foundation for high-rise building in Germany
}

\author{
O. A. Abdel-Azim ${ }^{1} \cdot$ K. Abdel-Rahman² ${ }^{2}$ Y. M. El-Mossallamy ${ }^{1}$
}

Received: 25 September 2019 / Accepted: 23 December 2019 / Published online: 17 January 2020

(c) The Author(s) 2020

\begin{abstract}
Piled rafts have been used as a foundation system for high-rise buildings worldwide in different soil conditions, e.g., in soft to stiff clay as well as in medium-to-dense sand. Piled raft is currently used not only to control the foundation settlement but also to minimize the required raft thickness to reach the most optimized foundation design. The purpose of this study is to investigate the behavior of piled raft as a foundation system for Frankfurt over-consolidated clay based on the well-monitored Messeturm building in Germany. The numerical tool used in analysis is Plaxis 3D finite element software with hardening soil material model. The piled raft foundation behavior will be evaluated based on the total settlement, differential settlement and the pile skin friction. Based on this study, it was found that the chosen foundation system "plied raft foundation" for Messeturm was an optimized solution for the proposed building.
\end{abstract}

Keywords Piled raft foundation $\cdot$ Over-consolidated clay $\cdot$ Finite element method $\cdot$ Hardening soil model

\section{Introduction}

In general, when constructing a low-rise building on a bearing layer of soil, shallow foundations can be used, but if the building is a high-rise building and contains a number of basements, raft foundation is normally chosen to support the entire structure. But in case of weak subsoil, raft on piles foundation system is used to transfer the load to deep bearing layers, and in case of a building founded on deeply extended non-bearing layer, it is a waste and an uneconomical solution to use long piles to reach the bearing layer.

In this case, the piled raft foundation system is considered to be one of the most economic foundation systems for these projects which are in the zone between the raft (relatively cheap) foundation system and raft on piles (very rigid and expansive) foundation system.

Piled raft is a composite foundation system that combines the bearing capacity of both the raft and the piles together, and its behavior depends on the complex interaction between

\section{K. Abdel-Rahman}

khalid@igth.uni-hannover.de

1 Structural Engineering Department, Faculty of Engineering, Ain Shams University, Cairo, Egypt

2 Deputy Head of Institute for Geotechnical Engineering (IGtH), Leibniz University Hannover, Hannover, Germany pile-soil, pile-raft, raft-soil and pile-pile. The piled raft foundation may be a good alternative solution; one of the most benefits of piled raft foundation is that there is no need to satisfy geotechnical bearing capacity; only the structural capacity is required as mentioned by [1].

Piled raft coefficient $\left(\alpha_{\mathrm{L}}\right)$ is defined as the ratio of load carried by the piles to the applied total load; when this coefficient is equal to zero, it is ideal raft foundation; when it is equal to 1 , it is conventional raft carried by the piles. Moreover, we can define another important coefficient $\left(\alpha_{\mathrm{S}}\right)$, coefficient of piled raft settlement reduction factor which is equal to settlement of piled raft to settlement of traditional raft; when it is equal to 1 , it is a raft foundation, while when it is equal to zero, it is the conventional raft on piles. The piled raft foundation ranges between 0.0 and 1.0 for both coefficients $\left(\alpha_{\mathrm{L}}\right.$ and $\left.\alpha_{\mathrm{S}}\right)$ as shown in Fig. 1.

\section{Previous investigations}

Kawabata [3] used the boundary element method (BEM) to investigate the piled raft foundation without considering the slipping behavior between the piles and soil. Clancy et al. [4] used the finite element method (FEM) for modeling of the piled raft. The raft was presented by a 4-node quadrilateral plate bending element, and the piles 
Fig. 1 Piled raft principles [2]
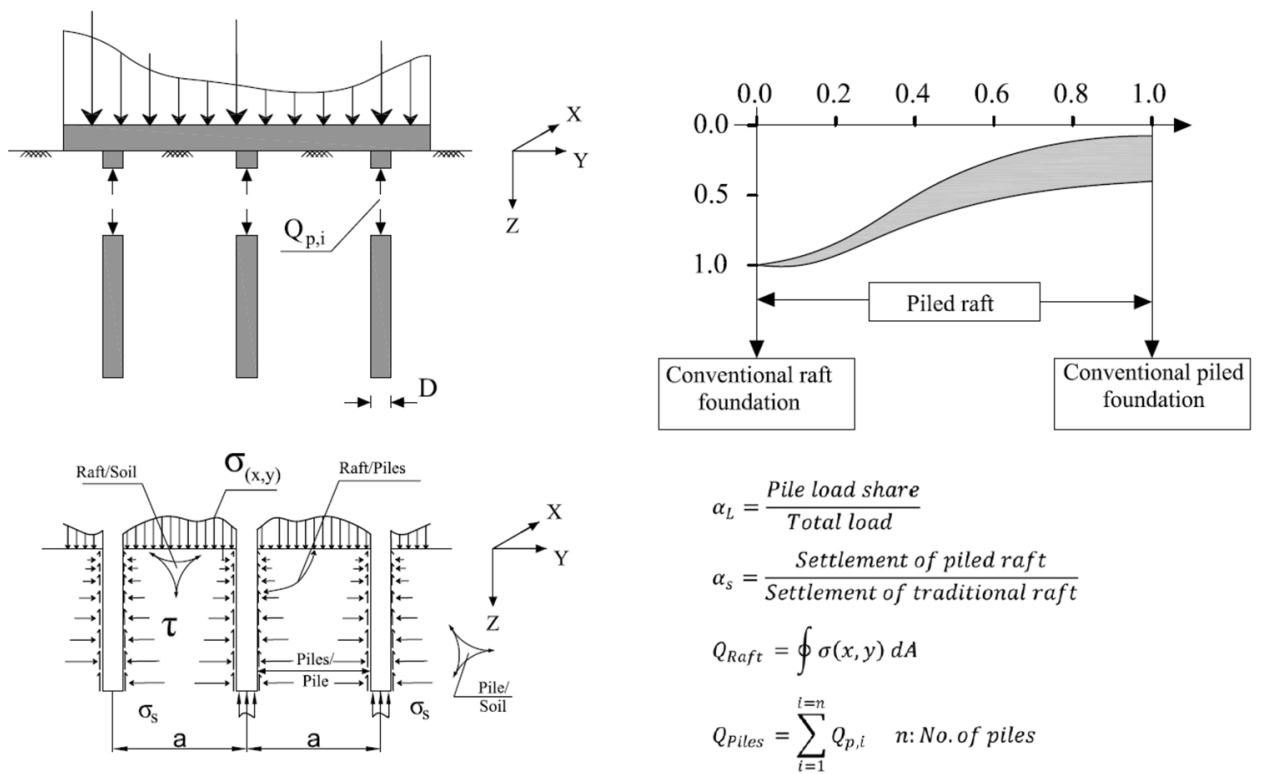

were modeled as beam elements. He discussed the effect of meshing by using the reduced integration concept to improve the numerical results. Ta and Small [5] studied piled raft in a layered soil. The piles and soil were simulated by numerical method called finite layer to represent the piles in the layered soil. The load distribution along the piles in the layered soil is affected by layers relative thickness and stiffness.

El-Mossallamy [6] studied numerically the piled raft in over-consolidated clay using two well-monitored buildings in Frankfurt: Messeturm and Westend Buildings. His method of analysis is a mixed technique where the raft is modeled using FEM, while the piles are modeled by BEM. The optimum design was achieved when the piled raft coefficient is between 0.4 and 0.6 . He found that the load taken by each single pile in the piled raft system depends on pile position, raft stiffness, on the configuration of the applied structural loads and on the load level.

Russo et al. [7] classified the piled rafts to small and large piled rafts. The settlement problem is mainly associated with large piled rafts as well as the differential settlement. They considered also the nonlinearity of piled raft system in their investigations. Prakoso and Kulhawy [8] used Plaxis finite element program but as 2D plain strain model. The pile dimension-to-raft width ratio has a big effect on both settlement and differential settlement.

De Sancits et al. [9] stated that the piled raft problem needs a 3D model to get an optimum design method, while 2D plain strain cannot be accurate enough. The bearing capacity block failure is accepted only when the width of pile group is the same as the raft width. Reul and Randolph et al. [10] used finite element program ABAQUS to study the behavior of piled raft via 3 buildings: Messeturm, Westend and Torhaus. The maximum settlement by piled raft can be reduced to be 51-63\% compared with the unpiled one. They found that the calculated piled raft coefficient by numerical analysis is higher than the measured values.

Mendonca et al. [11] used the mixed technique in which the interaction between piles-soil-raft is taken into account, and their results match well with the finite element method.

Reul [12] used the finite element method to model the piled raft in over-consolidated clay. He found that the reduced settlement can be achieved by using longer piles rather than using a higher number of piles. Navak et al. [13] investigated the load-settlement behavior using 3D finite element using two well-monitored buildings: Westend in Frankfurt clay and Urawa in Japan; both existed in overconsolidated clay. He compared the FEM with BEM. For the first building, the results are in good agreement. Balakumar [14] used ANSYS finite element program to study the performance of piled raft in sand. He found that the piles are fully mobilized without any failure observed. He found also that the piles load share decreases when settlement level also increases.

Oh et al. [15] used finite element (Plaxis) and finite difference (FLAC) methods to study the behavior of piled raft in sandy and clayey soil. They found that the maximum settlement depends mainly on the number of piles and the pile spacing. The differential settlement was reduced if the raft thickness increases. Sandeep et al. [16] stated that if the piled raft coefficient is initially high, then it decreases with stress increase; also, he stated that the differential settlement increases when Poisson's ratio increases. 
Katzenbach et al. [17] presented a 3D finite element model to simulate piled raft in a layered soil; he stated that the load carried by the raft is increased by increasing the pile spacing. Omar El-Kadi [18] used finite element Midas GTS software to study the performance of piled raft using embedded pile concept to simulate the piles. He found that the embedded pile cannot be used to get the failure load and C-phi reduction technique cannot be used to predict the capacity of pile group as well as the piled raft precisely.

Elarabi [19] adopted the finite element program Plaxis 3D Foundation to investigate the applicability of piled raft in soft clay under undrained condition. He found that by increasing the pile spacing in case of piled raft will lead to a larger settlement. Amr [20] used DIANA finite element method to investigate the piled raft in Port Said soft clay using soil profile consisting of fill with thickness of about 1 $\mathrm{m}$, followed by sand and silty sand with thickness of about $12 \mathrm{~m}$ underlain by a large extended Port Said soft clay; the foundation level is on the upper sand layer.

El-Wakil [21] used finite element method to simulate piled raft laboratory models; he concluded that by increasing the pile length, a better performance is obtained rather than by increasing number of the piles. S. Mil [22] used Plaxis 3D finite element program to investigate the behavior of piled raft in stiff clay. He found that by increasing the pile spacing-to-diameter ratio more than 6 will increase the settlement significantly as discussed in [23].

\section{Verification of the numerical model}

The verification of the presented numerical model will be compared via two cases; the first case is a simple single pile developed by Katzenbach [24, 25] as a conceptual verification, while the other case is Messeturm building, made by Sommer [26] and El-Mossallamy [6]. Both cases were founded on over-consolidated Frankfurt clay, so it is important firstly to state the main properties of Frankfurt subsoil formation.

\section{Frankfurt clay}

Frankfurt subsoil consists of sand and gravel layers up to $10 \mathrm{~m}$ from the ground surface underlain by over-consolidated clay to a large depth, followed by limestone as shown in Fig. 2. Frankfurt clay was over-consolidated by land formation with a value of the previous vertical stresses ranging from $500 \mathrm{kPa}$ to about $2500 \mathrm{kPa}$ [27]. The properties of Frankfurt clay are shown in Table 1.

These results are based on different samples taken from the site of Main Tower building. For Frankfurt clay, El Mossallamy [6] reported that the difference between the short-term and long-term conditions is minor, and for a single pile, the effect is about $6.0 \%$ to $15.0 \%$, while for piled raft case, the effect of consolidation may reach $30 \%$.

Table 1 Average properties of Frankfurt clay and limestone [24, 25]

\begin{tabular}{llll}
\hline Properties & Units & Frankfurt clay & $\begin{array}{l}\text { Frankfurt } \\
\text { limestone }\end{array}$ \\
\hline Angle of friction & Degrees & 20 & 32.5 \\
Cohesion & $\mathrm{kPa}$ & 20 & 15 \\
Uniaxial strength & $\mathrm{MPa}$ & 0.28 & 84 \\
Young's modulus & $\mathrm{MPa}$ & 50 & 20.000 \\
Coefficient of earth & - & 0.6 & 0.5 \\
Pressure at rest & & & \\
Unit weight of soil & $\mathrm{kN} / \mathrm{m}^{3}$ & $1 \mathrm{~S} .5$ & 20 \\
Buoyant unit weight & $\mathrm{kN} / \mathrm{m}^{3}$ & $\mathrm{y}$ & 10 \\
Natural water content & $\%$ & 34 & - \\
Liquid limit & $\%$ & 74 & - \\
Consistency index & - & 0.82 & - \\
\hline
\end{tabular}

Fig. 2 Soil profile in Frankfurt City [24, 25]

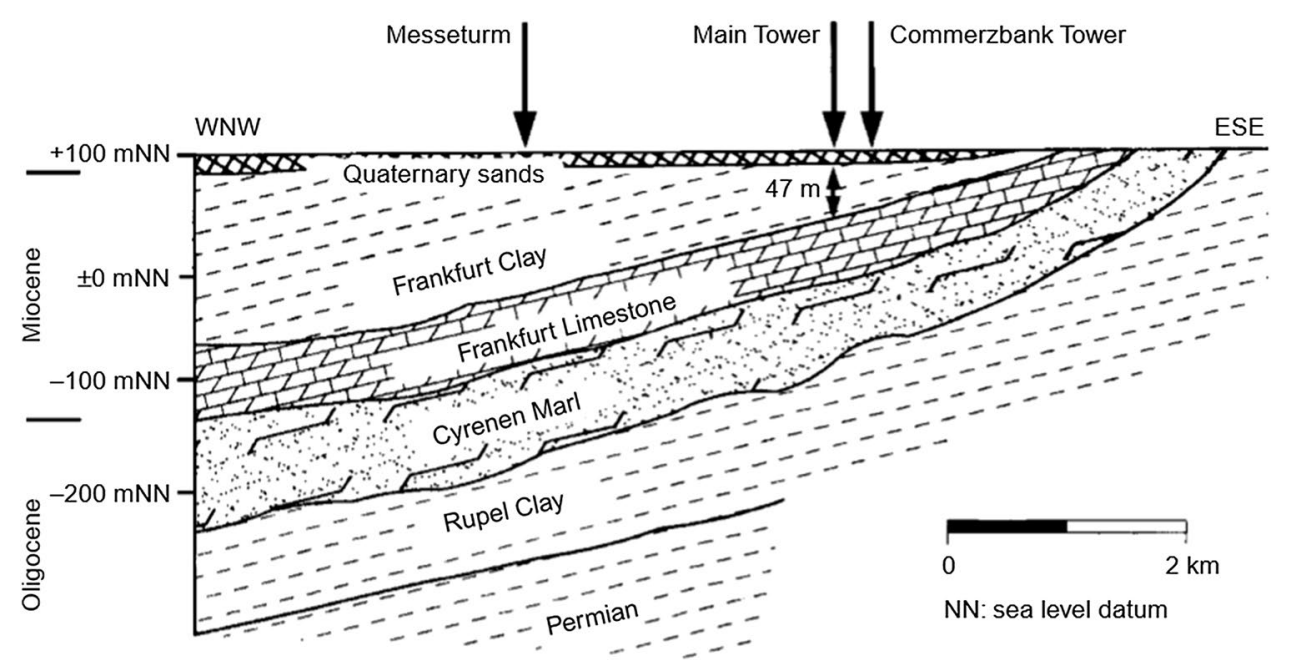




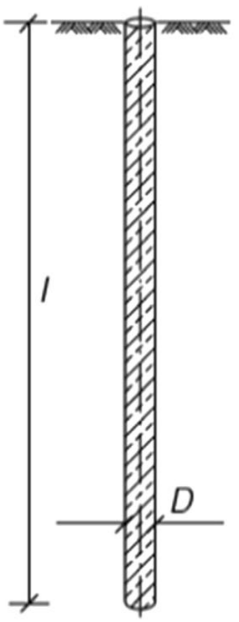

(a)

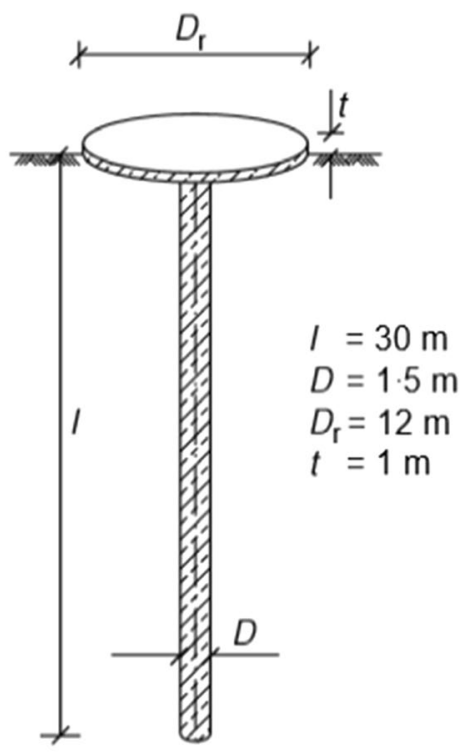

(b)

\section{Single pile}

First numerical task has been done as a conceptual verification based on Katzenbach finite element work [24]. He studied a single pile embedded in Frankfurt clay numerically and compared the effect of the raft on the pile performance. The modeled pile was a bored pile of $30 \mathrm{~m}$ long with diameter $1.50 \mathrm{~m}$. The dimension of circular raft was $12 \mathrm{~m}$ in diameter and has $1 \mathrm{~m}$ thickness (Fig. 3).

The computations were carried out using the finite element program Plaxis. A 2D-axisymmetric model with triangular (15 nodes) is used to examine the behavior of a freestanding pile and pile raft in clay soil under vertical axial loading conditions. An exemplary finite element mesh is shown in Fig. 4.

Close to the pile, a very fine discretization is used to ensure accurate results. The model dimensions of a width equal to 20 times the pile diameter or equal to 5 times the raft width and a depth equal to 2.5 times the pile length were chosen to ensure that the numerical results are not affected by the boundary conditions.

For the numerical modeling, a linear elastic material behavior for concrete was assumed with the parameters
Fig. 4 Finite element mesh for single pile and piled raft model

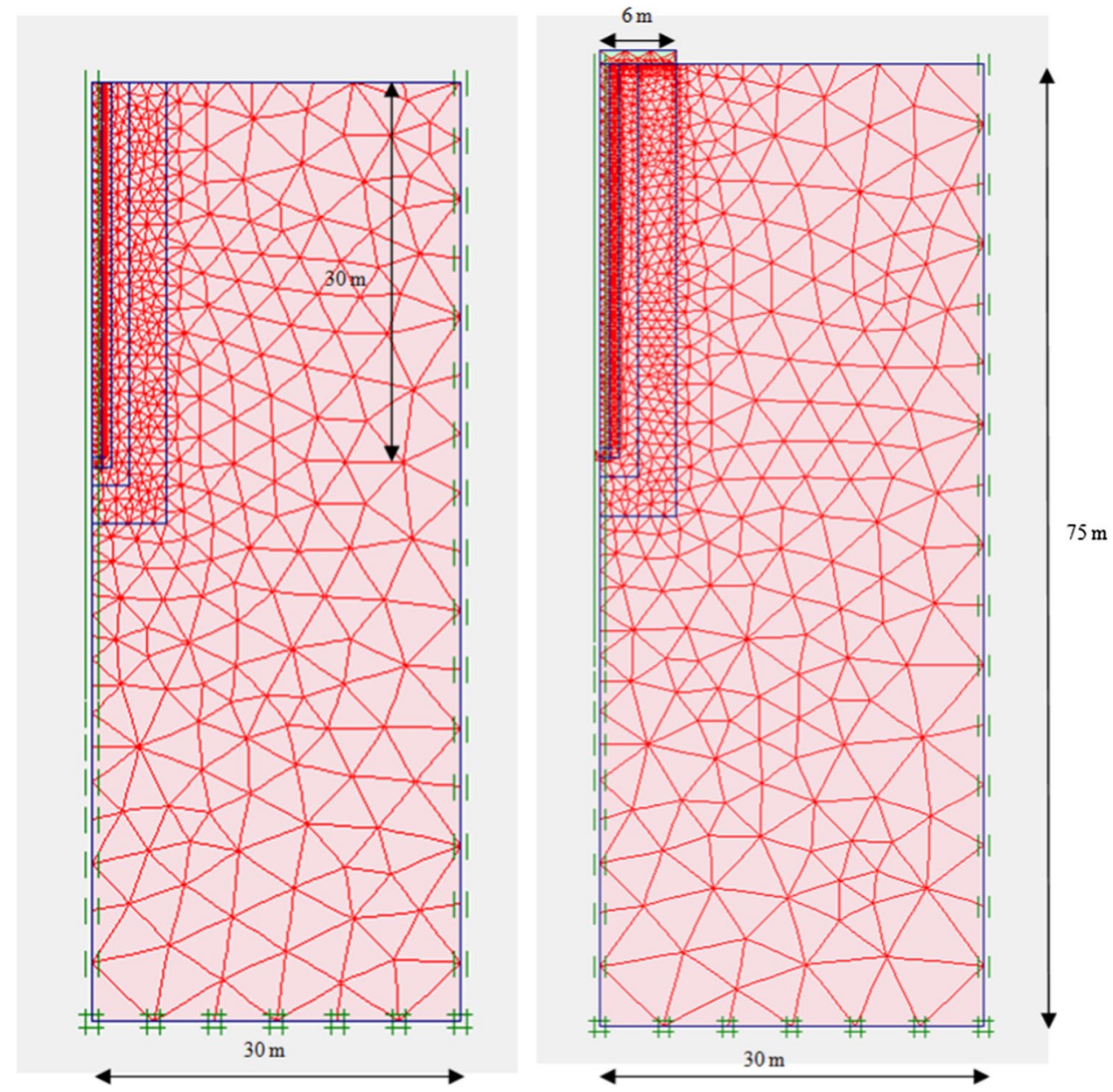


$E=3.0 \cdot 10^{4} \mathrm{MN} / \mathrm{m}^{2}$ (Young's modulus) and $\nu=0.25$ (Poisson's ratio).

To account for the nonlinear soil behavior, elasto-plastic material behavior was considered for the soil elements. A hardening soil material model was adopted for the numerical modeling.

This material model is considered as an advanced model for soil simulation, where the elastic deformation is represented by three input values instead of one value as in the case of the Mohr-Coulomb Model. The input moduli are the triaxial loading modulus $\left(E_{50}\right)$ [Eq. (1)], the triaxial unloading modulus $\left(E_{\text {ur }}\right)($ Eq. $(2))$ and the oedometer modulus $\left(E_{\mathrm{oed}}\right)$. The difference between the input soil moduli is shown in Fig. 5.

$E_{50}=E_{50}^{\mathrm{ref}}\left(\frac{C^{\prime} \cot \varphi^{\prime}+\sigma_{3}^{\prime}}{C^{\prime} \cot \varphi^{\prime}+p^{\text {ref. }}}\right)^{m}$

$E_{\mathrm{ur}}=E_{\mathrm{ur}}^{\mathrm{ref}}\left(\frac{C^{\prime} \cot \varphi^{\prime}+\sigma_{3}^{\prime}}{C^{\prime} \cot \varphi^{\prime}+p^{\text {ref. }}}\right)^{m}$

where $E_{50}=$ reference stiffness modulus at confining pressure $\left(p^{\text {ref }}\right) 100 \mathrm{kPa} ; E_{\mathrm{ur}}=$ reference unloading stiffness modulus at confining pressure $\left(p^{\text {ref }}\right) 100 \mathrm{kPa} ; C^{\prime}$ and $\varphi^{\prime}=$ effective shear parameters; $m=$ factor which represents the stress level dependency of the stiffness; its value ranges between 0.4 and 1.0 according to the type of the soil.

The soil stiffness in this model depends on the stress level and on the stress path; moreover, it takes the unloading and reloading behavior of the soil into consideration. The yield surface is not fixed, but it can be expanded due to straining; moreover, the dilatancy can be cut off and the failure criterion is adapted according to the Mohr-Coulomb failure criterion.

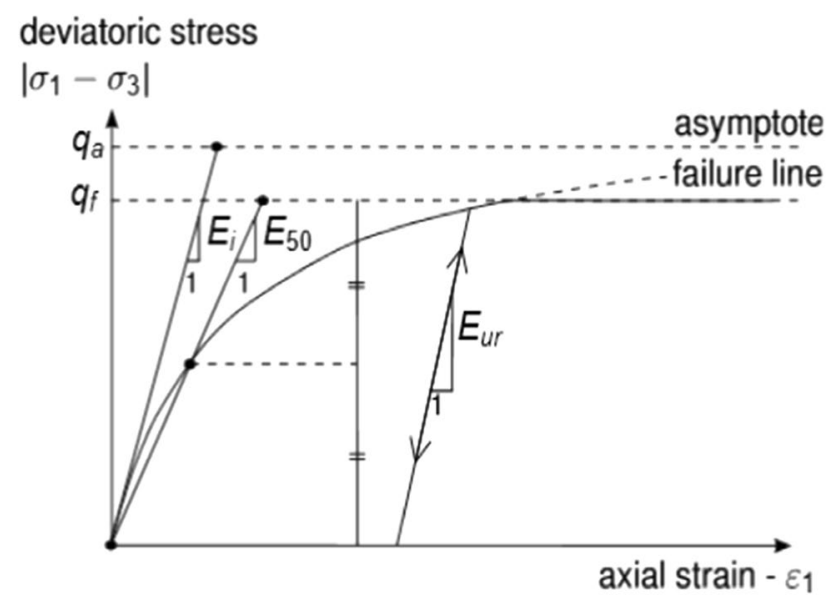

Fig. 5 Relation between deformations moduli of hardening soil module and stress-strain relationship [30]
The model takes into account both shear and compression hardening $[28,29]$ (sometimes it is called a double hardening model); shear hardening occurs due to primary deviatoric loading, while compression hardening occurs due to isotropic loading and primary compression.

The hardening soil parameters used in analysis are listed in Table 2.

The numerical calculation is divided into several steps. In the first step, the initial stress state is generated by consideration of soil elements only. Afterward, the soil elements located at the pile position are removed and replaced by pile elements (wished in place), and the pile/raft own weight and contact conditions are activated. Finally, the prescribed settlements are applied on the top of pile or to the raft.

In Katzenbach study [24], each case was investigated under three different settlements. For the free-standing pile case, the three displacement values were $0.005 \mathrm{D}(7.5 \mathrm{~mm})$, $0.01 \mathrm{D}(15 \mathrm{~mm})$ and $0.1 \mathrm{D}(150 \mathrm{~mm})$, and the corresponding axial forces were 5.0, 8.0 and 13.0 MN, respectively. In the other case by connecting the raft to the same pile under the same settlement values, the values of loads transferred to the piles were 4.0, 6.0 and $12.0 \mathrm{MN}$, respectively.

From Fig. 6, the skin friction under small displacement is not fully mobilized and remains almost constant $(37 \mathrm{kN} /$ $\mathrm{m}^{2}$ under $5 \mathrm{MN}$ ) along the depth; then, it increases gradually until it reaches its final mobilized value (linear distribution) under $13 \mathrm{MN}$.

For the second case, Fig. 7 shows the distribution of skin friction along the pile length. Under smaller loads (up to $6 \mathrm{MN}$ ), the skin friction increases linearly with the depth. Under the higher loads (12 MN), the peak of skin friction will be localized directly under the raft (up to $97 \mathrm{kN} / \mathrm{m}^{2}$ ) due to the high applied pressure.

Figures 8 and 9 show the verification of the numerical model done by the authors and the numerical study done by Katzenbach [24]. Figure 8 shows the comparison regarding the skin friction along the pile shaft for the free-standing

Table 2 Material parameters in the analysis [31]

\begin{tabular}{llll}
\hline Parameter & Name & Frankfurt clay & Unit \\
\hline Type of material & Type & Drained & - \\
Soil unit weight above GWT & $\gamma_{\text {unsat }}$ & 20 & $\mathrm{kN} / \mathrm{m}^{3}$ \\
Soil unit weight below GWT & $\gamma_{\text {sat }}$ & 20 & $\mathrm{kN} / \mathrm{m}^{3}$ \\
Secant stiffness & $\mathrm{E}_{50}^{\text {ref }}$ & $4.5 \times 10^{4}$ & $\mathrm{kN} / \mathrm{m}^{2}$ \\
Oedometer stiffness & $\mathrm{E}_{\text {oed }}^{\text {ref }}$ & $4.5 \times 10^{4}$ & $\mathrm{kN} / \mathrm{m}^{2}$ \\
Unloading-reloading stiffness & $\mathrm{E}_{\mathrm{ur}}^{\text {ref }}$ & $9.0 \times 10^{4}$ & $\mathrm{kN} / \mathrm{m}^{2}$ \\
Poisson ratio & $v$ & 0.3 & - \\
Power & $\mathrm{m}$ & 0.5 & - \\
Cohesion & $\mathrm{C}$ & 20 & $\mathrm{kN} / \mathrm{m}^{2}$ \\
Internal friction angle & $\varphi$ & 20 & $\circ$ \\
Lateral earth pressure coefficient & $\mathrm{K}_{0}$ & 0.8 & - \\
\hline
\end{tabular}


Fig. 6 Load-settlement curve; skin friction along pile shaft; free-standing pile [24, 25]
Fig. 7 Load-settlement curve; skin friction along the pile shaft; pile connected with raft $[24,25]$
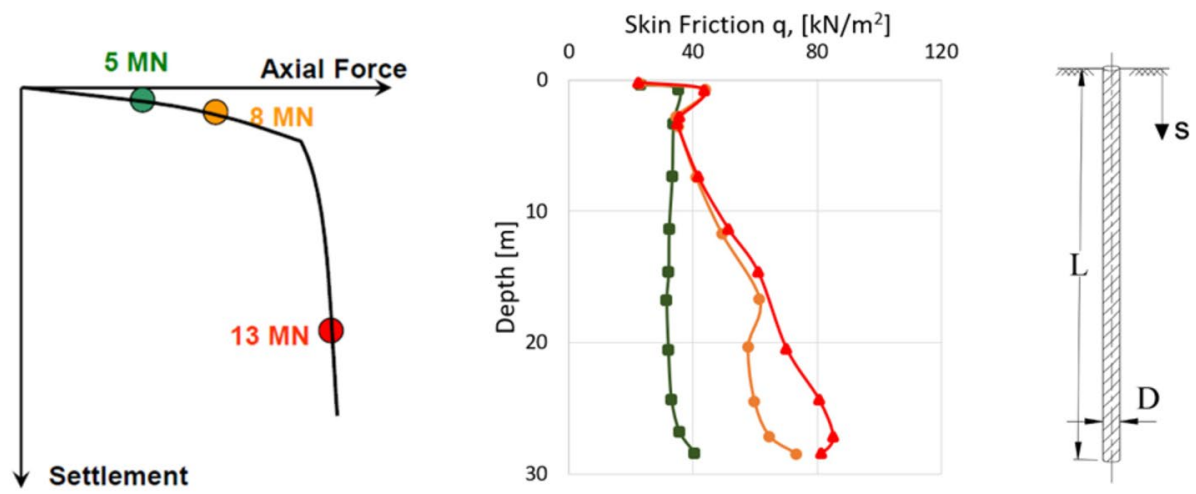

$-\mathrm{C}=0.005 \mathrm{D}$

$-S=0.01 \mathrm{D}$

$\leftarrow S=0.1 \mathrm{D}$

$\mathrm{S}=$ Settlement

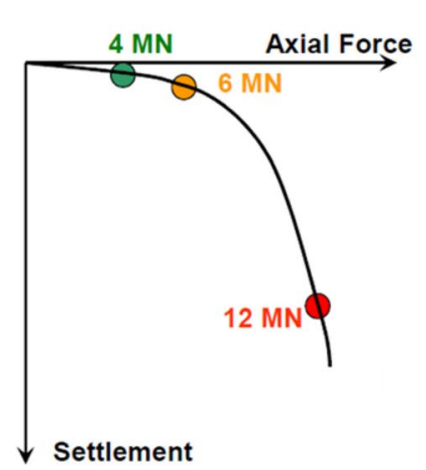

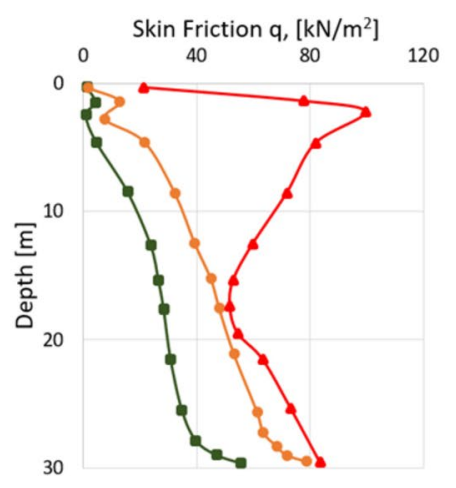

$-S=0.01$
$-S=0.1 \mathrm{D}$

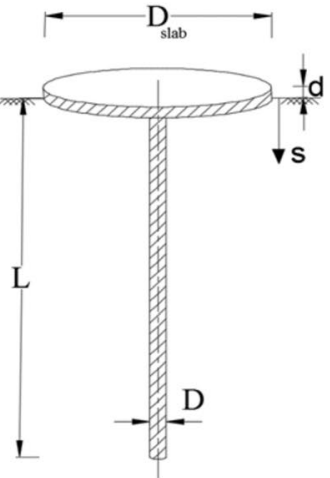

$\mathrm{S}=$ Settlement pile, while Fig. 9 shows the skin friction distribution for the piled raft case.

Form Fig. 8, it is obvious that at the low-stress level (up to $7.50 \mathrm{~mm}$ ), the skin friction is almost constant along the pile length. By increasing the prescribed settlement from $7.5 \mathrm{~mm}$ to $15 \mathrm{~mm}$, the mobilized skin friction increases and reaches its maximum value at the pile tip. In the last stage, by increasing the pile settlement from $15 \mathrm{~mm}$ to $150 \mathrm{~mm}$, a sufficient relative displacement between the pile and the soil will mobilize both cohesion and friction to its maximum value.

The effect of connecting raft to the pile is presented in Fig. 9. Under the prescribed settlement, the settlement caused by the raft reduces the relative displacement between the pile and the surrounding soil, especially in the upper domain near the raft application. For higher prescribed settlement, an additional deformation has been produced, and its value depends on the used constitutive laws, which is the reason for the massive skin friction in the upper part. In the lower part, the relative displacement decreases with depth.
There is a very good agreement between our results and the previous numerical results reported by Katzenbach, under small displacement up to $15 \mathrm{~mm}$. But a relatively small deviation is observed especially for $150-\mathrm{mm}$ settlement for the second case due to the higher contact stress under the raft compared with the same settlement in the free-standing pile due to raft contribution. Based on these results, the numerical model has been verified and can be adopted for further investigation cases.

\section{Case study (Messeturm)}

\section{Description}

A building with $256 \mathrm{~m}$ height with two basements with the total area of $58.80 \mathrm{~m} \times 58.80 \mathrm{~m}$, has central core shaft in the middle with dimensions $41.0 \mathrm{~m} \times 41.0 \mathrm{~m}$ and with height $210 \mathrm{~m}$. The proposed foundation system is piled raft system with a thickness of $6 \mathrm{~m}$ in the middle which decreases linearly to $3 \mathrm{~m}$ at the edges. The raft is carried by 64 large 


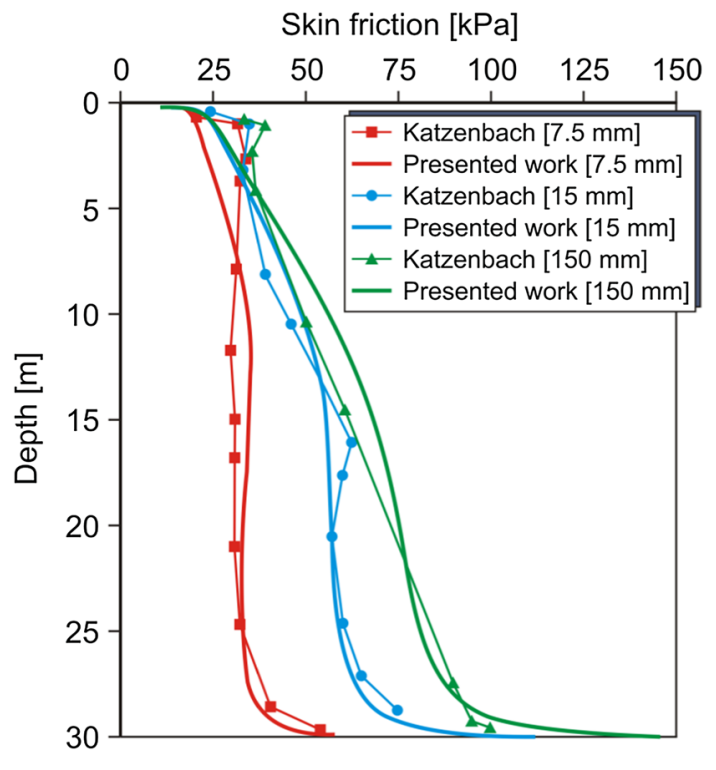

Fig. 8 Skin friction with depth in case of free-standing pile

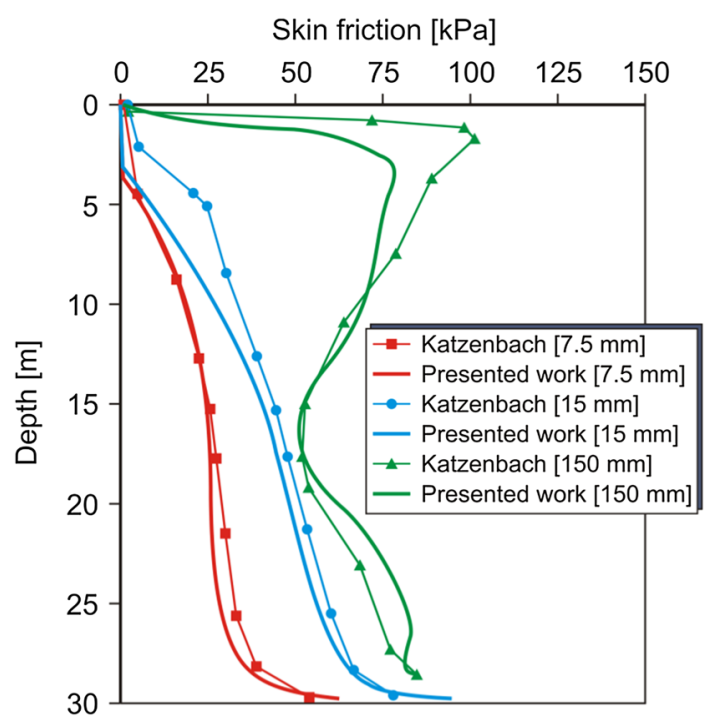

Fig. 9 Skin friction with depth for a single pile connected with raft

diameter bored piles with $1.3 \mathrm{~m}$ diameter, and the pile lengths differ according to its position in the raft.

The bored piles are distributed in three rings; in the inner ring, the piles length is $34.90 \mathrm{~m}$; in outer ring, the piles length is $26.90 \mathrm{~m}$, and in the middle ring, the piles length is $30.90 \mathrm{~m}$. The pile spacing varies from $3.5^{*} \mathrm{D}$ up to $6^{*} \mathrm{D}$ according to their position in the raft. The piles are concentrated mainly under the central core of the Messeturm to be near the heavy loads coming from the core to reduce the straining action in the raft and also to control the differential settlement.
The foundation level of the building is located $14 \mathrm{~m}$ below the ground surface; the total weight of the building is $1880.0 \mathrm{MN}$ with average stress on the raft of $544.0 \mathrm{kPa}$, while the uplift force is about 276.0 MN. A simplified calculation approach was used for a preliminary design of the foundation system to calculate the raft size and pile distribution. The total pile loads were assumed to depend on the mobilized skin fiction and carry 55\% of the total load. The behavior of the foundation was monitored during the construction period and for more than 7 years after the finishing of construction by means of geodetic and geotechnical measurements using 12 instrumented piles, 13 contact pressure cells, one pore pressure cell and three multi-point borehole extensometers as shown in Fig. 10.

The results of the field measurements indicate that the load-bearing behavior of the Messeturm piled raft foundation has been optimized. However, the design concept assumed that the piles would reach their ultimate bearing capacity by the settlements caused by the structural load; thereafter, transferring any additional load increments to the raft could not be proved by field observations. The measured pile loads show that much higher skin friction has been mobilized than that determined for a single isolated bored pile.

\section{Numerical model}

The computations were carried out using the finite element program Plaxis 3D. A 3D-numerical model with 10-noded elements is developed to investigate the behavior of a piled raft foundation for Messeturm founded on Frankfurt clay and compared with numerical results developed by Sommer [26] and El-Mossallamy [6].

The finite element mesh is shown in Fig. 11. Close to the piles, a very fine discretization is used to ensure accurate results. The chosen model dimensions in $x, y$ and $z$ are 300.0, 300.0 and $90.0 \mathrm{~m}$, respectively. These dimensions have been chosen to be large enough to minimize the effect of the model boundaries on the numerical results (see Fig. 11). Also, the model depth was taken the maximum of 2.5 times the length of piles or the depth were the increase in stresses of the building becomes smaller than $20 \%$ of the overburden pressure.

The boundary conditions were applied as follows:

1. The ground surface is free in all directions.

2. Vertical model boundaries with their normal in $x$-direction are fixed in $x$-direction and free in $y$ - and $z$-direction.

3. Vertical model boundaries with their normal in $y$-direction are fixed in $y$-direction and free in $x$ - and $z$-direction.

4. The model bottom boundary is fixed in all directions. 
Fig. 10 Applied measurements on the foundation system of Messeturm [6]

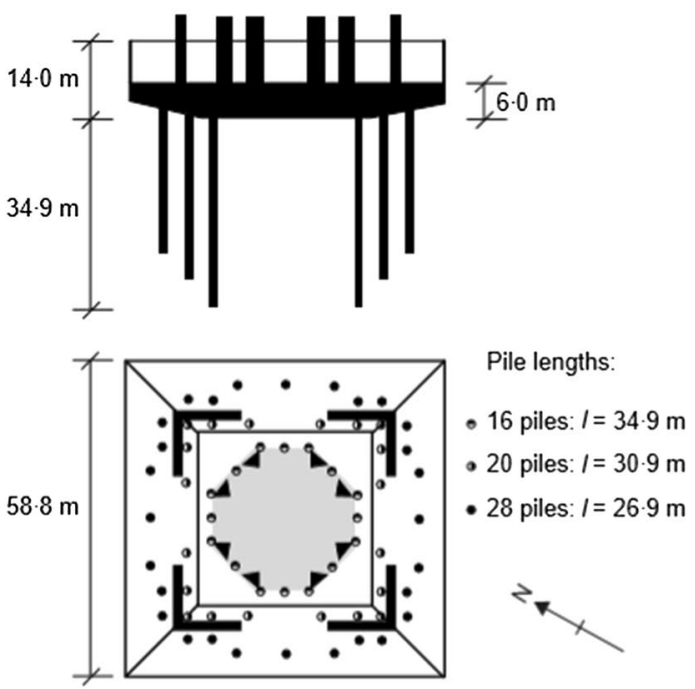

(a)
- $1-12$

instrumented piles

$\odot$ EX1-EX3

extensometers

$\square 11$ raft pressure cells

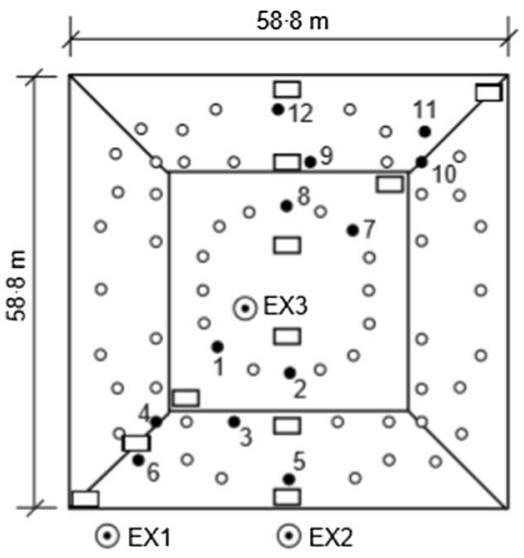

(b)

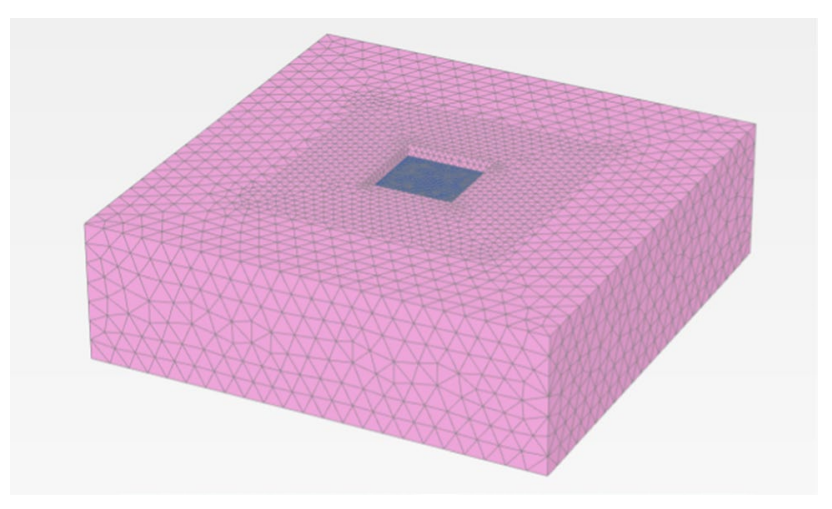

Fig. 11 Finite element mesh

Due to Frankfurt clay nature as mentioned before, the clay was overloaded by heavy loads with average stress ranging between 500.0 and $2500.0 \mathrm{kPa}$, so the Over Consolidation Ratio (OCR) ranged over specific values and it was difficult to find out the exact value of OCR without performing a consolidation test.

There are many correlations, which relate OCR with several parameters, for example $K_{\text {Ooc }}=K_{\text {onc }}(\mathrm{OCR})^{\mathrm{m}}$ reported by Meyerhof 1976 [32] where $m=0.5$, and the OCR for Frankfurt clay, in this case, is 1.50 . For the presented study, several values of OCR will be investigated using values above and below 1.50 (see Table 3). Another technique for defining the over-consolidation pressure is adopted in the hardening soil model which is the pre-overburden pressure (POP) technique instead. The difference between both of them is illustrated in Fig. 12.
Table 3 The settlement and $\alpha_{\mathrm{L}}(\%)$ for different OCR values as well as POP

\begin{tabular}{llllll}
\hline & \multicolumn{2}{l}{ OCR } & & POP \\
\cline { 2 - 5 } & 1.25 & 1.50 & 1.75 & 2 & $700 \mathrm{kPa}$ \\
\hline Settlement $(\mathrm{cm})$ & 13.211 & 12.276 & 11.825 & 11.639 & 11.342 \\
$\alpha_{\mathrm{L}}(\%)$ & 57.1 & 56 & 55.2 & 54.4 & 54.6 \\
\hline
\end{tabular}

For the raft, a linear elastic material model was adopted, and the model assumes a linear relationship between the stress and the strain. This material model needs two parameters: the modulus of elasticity $(E)$ and Poisson ratio $(v)$. For the raft, $E=30,000 \mathrm{MPa}, v=0.167$, while for piles, $E=22,000 \mathrm{MPa}, v=0.20$.

The piles were modeled as "embedded elements." In this case, the piles do not have a "real" volume or a "real" interface. However, a virtual elastic zone is created by assigning an equivalent pile diameter within the material data set of the embedded pile. This virtual elastic zone disregards the plastic behavior of the soil within the zone and approaches the actual volume pile behavior. On the other hand, due to the "virtual" volume and interface, evaluation of the effect of strength reduction factor $\left(\mathrm{R}_{\text {inter }}\right)$ cannot be realized. $\mathrm{R}_{\text {inter }}$ is taken as rigid (1.0) with the assumption that the interface does not have a reduced strength with respect to the strength in the surrounding soil.

The steps of the numerical model are summarized as follows: 


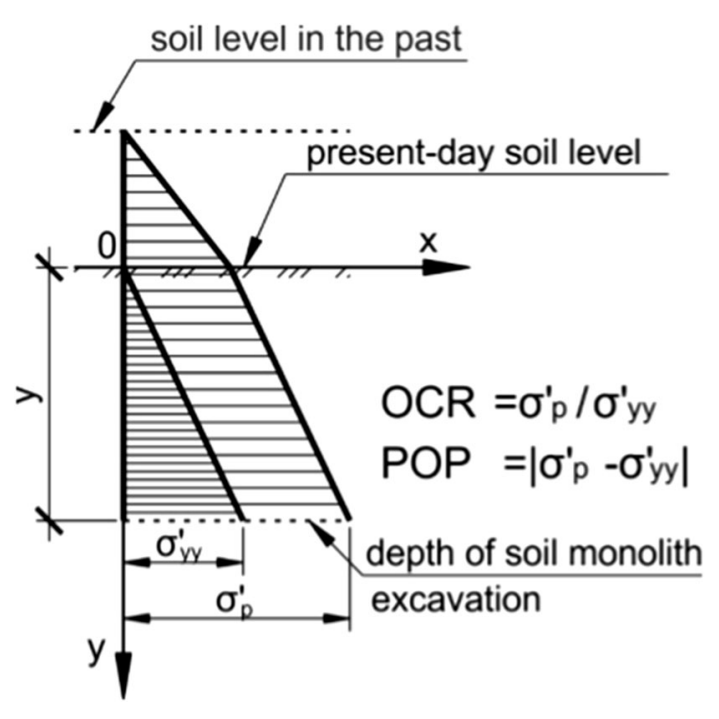

Fig. 12 Difference between OCR and POP

1. Firstly, in-situ stress state or it is also called primary stress conditions is applied. In the step, only the own weight of the soil domain will be activated.

2. Then, the soil excavation up to a depth of $8 \mathrm{~m}$ below GL will be done. This was modeled by deactivation of the soil element from ground surface up to $8.0 \mathrm{~m}$. Keep in mind that the excavation sides were kept in equilibrium by supporting them horizontally in $\mathrm{x}$ - or in $\mathrm{y}$-direction.

3. In the third step, the installation of piles as embedded elements was done by activating the beam elements and the contact conditions along them in the three different rings (inner, middle and outer).

4. Consequently, a further excavation up to $14 \mathrm{~m}$ below ground level was done. This step is necessary in order to construct the concrete piled raft. Then, the own weight of the raft and the interface elements between the raft and subsoil have been activated taken into consideration the uplift water pressure. This means the own weight will be reduced by almost $60 \mathrm{kN} / \mathrm{m}^{2}$.

5. Finally, the vertical loading representing the own weight of the high-rise building is out on the upper surface of the raft.

\section{Numerical results}

Figure 13 shows the verification of the hardening soil model results with four different OCR values $1.25,1.5,1.75$ and 2.0. The numerical results show that the curve with OCR value equal to 1.50 is nearest to the measured one, as the total settlement is about $12.27 \mathrm{~cm}$ compared with $12.0 \mathrm{~cm}$ measured value under the same vertical loading, but it is also shown that the effect of OCR value on the behavior is minor.

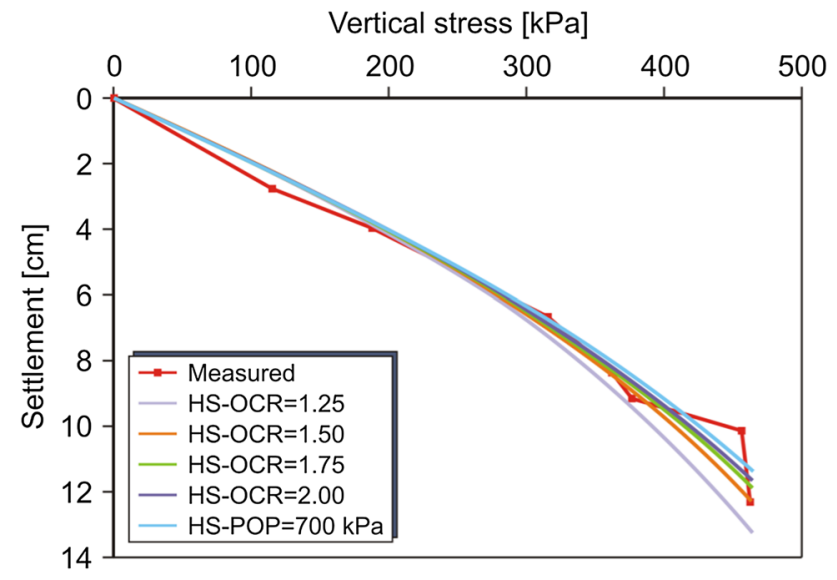

Fig. 13 Vertical stress-settlement curves for different OCR values

Table 3 summarizes the results of hardening soil model using the previous OCR values. When the OCR slightly increases, this will reduce the pile share $\left(\alpha_{\mathrm{L}}\right)$ due to the increase in soil stiffness, which will increase the soil share, and consequently, the pile load coefficient $\left(\alpha_{\mathrm{L}}\right)$ will be reduced from $57 \%$ to $54 \%$.

In the case of using pre-overburden pressure (POP) of $700.0 \mathrm{kPa}$, the reached settlement in this case was $113 \mathrm{~mm}$, which is near to the obtained value by OCR that is equal to 1. 50 .

Figure 14 shows the differential settlement between the center of raft and its edge as a function of the applied vertical stress on the raft. It can be noticed that for the three presented results (numerical molding of the authors, measured values and the results reported by El-Mossalamy [6]), the differential settlement increases with the applied vertical stress. Our numerical results show a good agreement, but it is slightly less than observed values;

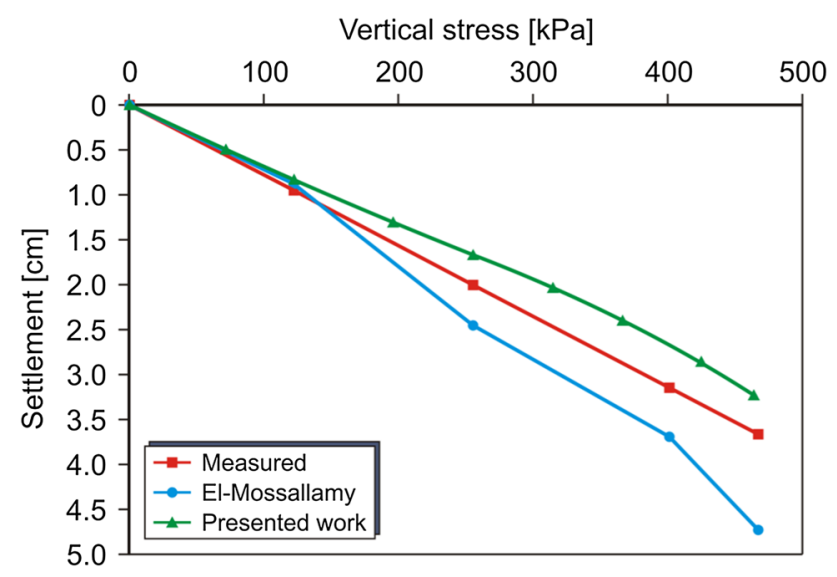

Fig. 14 Vertical stress-differential settlement curves 
this means that the numerical model for the piled raft has more stiffness than the reality.

Figure 15 shows the settlement contour after application of the total vertical load. Under the own weight of raft, the vertical settlement was almost constant with a maximum value of $2.4 \mathrm{~cm}$, by applying the total vertical load on the raft, a higher increase in the vertical settlement of the piled raft system up to $12.0 \mathrm{~cm}(\mathrm{OCR}=1.50)$.

Figure 16 shows the skin friction distribution for a selective pile in the middle ring. The embedded pile element in Plaxis 3D gives directly the skin friction as force/ unit length, and then, it can be transformed manually to skin friction along the pile length. The results in Fig. 16 show a good agreement with the previous results obtained by El-Mossallamy [6]; both of them show comparable distribution up to a depth of $20.0 \mathrm{~m}$. The maximum skin friction was almost $130 \mathrm{kN} / \mathrm{m}^{2}$, which is comparable with the measured value of $140.0 \mathrm{kN} / \mathrm{m}^{2}$. This confirms the applicability of the numerical model to predict the behavior of piled raft in over-consolidated clay.

\section{Conclusions}

This article presents the results of numerical analysis of the piled raft foundation for over-consolidated clay using 3-D finite element analysis. Firstly, the numerical model has been verified by comparing our results with a previous numerical study reported by Katzenbach for free-standing pile and for

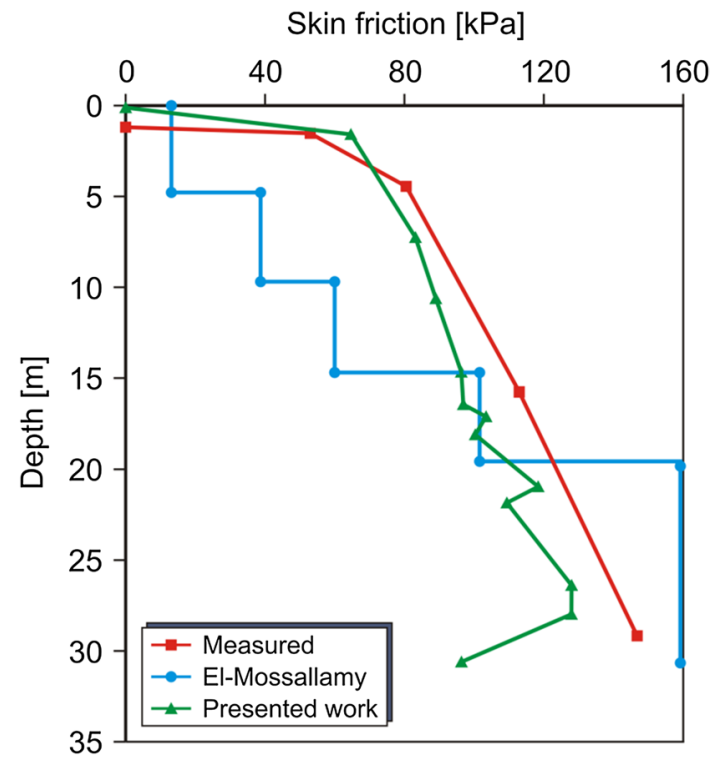

Fig. 16 Skin friction distribution along a pile in the middle ring $(\mathrm{L}=30.90 \mathrm{~m})$

a pile connected to circular raft. The comparison shows a very good agreement between the results under small loading conditions. But a relatively small deviation was observed for a higher vertical loading.

Then, a finite element model of Messeturm piled raft foundation was developed. The hardening soil material model is used to simulate the over-consolidated Frankfurt

Fig. 15 Settlement contour in cross section under total vertical load

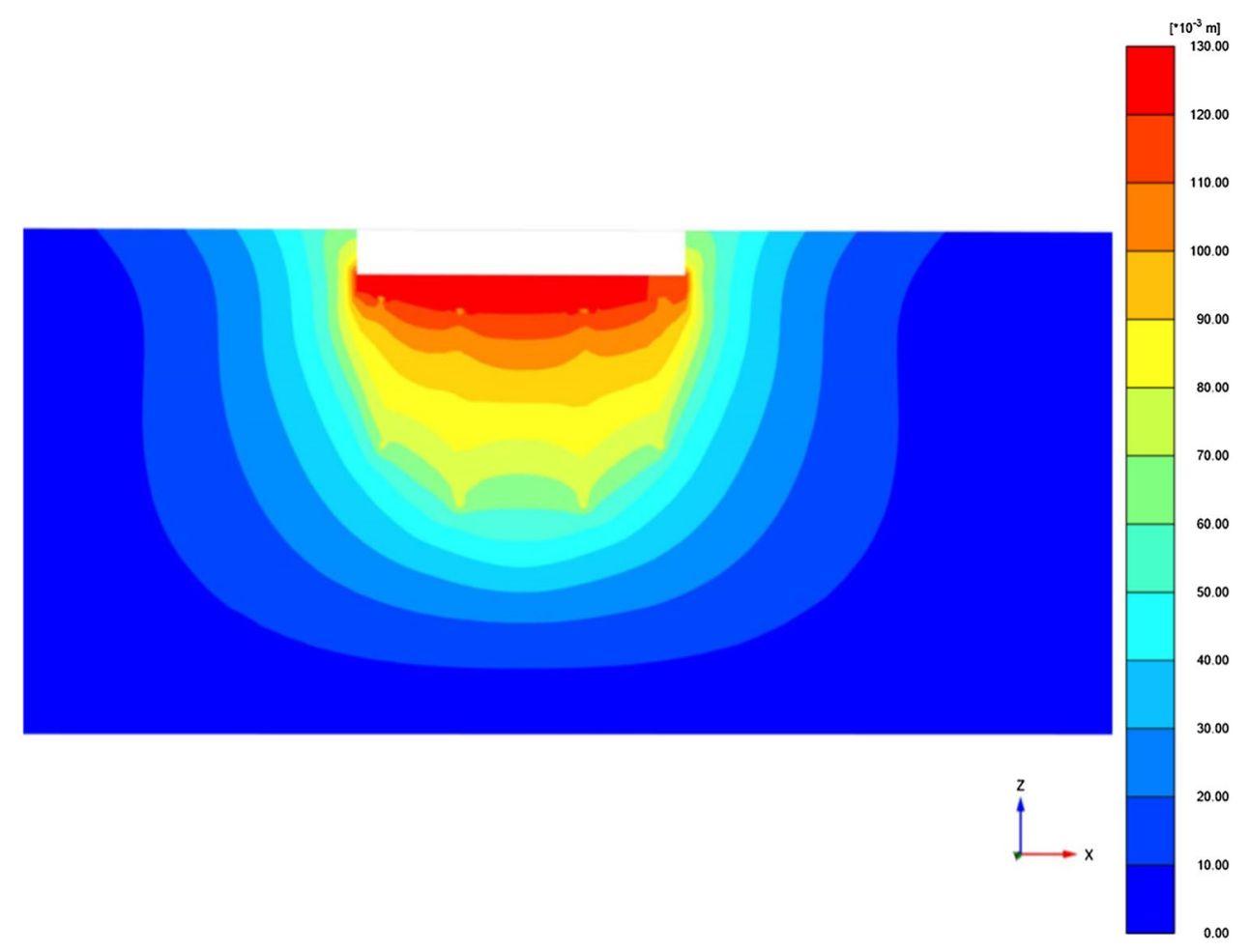


clay; moreover, the embedded beam element concept was adopted for the piles as it is a quick tool to simulate piles under service load but not to predict precisely the ultimate pile load capacity. The numerical results show a good agreement with measurement made for the foundation for the "Messeturm" regarding the raft settlement and skin friction distribution along the piles.

Finally, this study indicates that piled raft foundation concept has significant advantages in comparison with conventional foundation systems and can be considered as optimized solution for high-rise building founded on overconsolidated clay.

Acknowledgements Open Access funding provided by Projekt DEAL.

Open Access This article is licensed under a Creative Commons Attribution 4.0 International License, which permits use, sharing, adaptation, distribution and reproduction in any medium or format, as long as you give appropriate credit to the original author(s) and the source, provide a link to the Creative Commons licence, and indicate if changes were made. The images or other third party material in this article are included in the article's Creative Commons licence, unless indicated otherwise in a credit line to the material. If material is not included in the article's Creative Commons licence and your intended use is not permitted by statutory regulation or exceeds the permitted use, you will need to obtain permission directly from the copyright holder. To view a copy of this licence, visit http://creativecommons.org/licenses/by/4.0/.

\section{References}

1. Katzenbach R, Choudhury D (2013) Combined pile-raft foundation guideline. ISSMGE international society of soil mechanics and geotechnical engineering, institute and laboratory of geotechnics, Technical University of Darmstadt, Germany

2. El-Mossallamy YM (1999) Load-settlement behavior of large diameter bored piled in over-consolidated clay. In: The 7th international symposium on numerical models in geotechnical engineering, Graz, Austria

3. Kuwabara F (1989) An elastic analysis for piled raft foundation in a homogenous soil. Soils and foundations. Jpn Soc Soil Mech Found Eng 29(1):82-92

4. Clancy P, Griffiths S (1991) A spurious zero energy mode in the numerical analysis of piled raft foundations. Comput Geotech 11:159-170

5. Ta LD, Small JC (1996) Analysis of piled raft systems in layered soils. Int J Numer Anal Methods Geomech 2:57-72

6. El-Mossallamy YM, Franke E (1997) Piled rafts: numerical modeling to simulate the behavior of piled raft foundations. $\mathrm{PhD}$ thesis, Darmstadt, university

7. De Sanctis L, Mandolini A, Russo G, Viggiani C (2002) Some remarks on the optimum design of piled rafts. Deep Foundations 2002, ASCE, 405-425

8. Prakoso WA, Kulhawy F (2000) Contribution to piled raft foundation design. J Geotech Geoenv Eng ASCE 127(1):17-24

9. Viggiani C (2001) Analysis and design of piled foundations. 1st Arrigo Croce Lecture, Rivista Italiana di Geotecnica, No. 1/2001, pp 47-75

10. Reul O, Randolph MF (2003) Piled rafts in over-consolidated clay: comparison of in situ measurements and numerical analyses. Géotechnique 53(3):301-315
11. Mendonca AV, Paiva JB (2003) An elastostatic FEM/BEM analysis of vertically loaded raft and piled raft foundations. Eng Anal Bound Elem 27:919-933

12. Reul O (2004) Numerical study of the bearing behavior of piled rafts. Int J Geomech 4(2):59-68

13. Novak JL, Reese LC, Wang ST (2005) Analyses of Piled Raft Foundation with 3D Finite Element Method. In: Structures congress, metropolis and beyond, pp 1-12

14. Balakumar V (2008) Experimental studies of model piled rafts on sand and field study of prototype behavior, $\mathrm{PhD}$ thesis, Anna University, Chennai, 600025

15. Oh EYN, Huang M, Surrak C, Adamec R, Balasurbamaniam AS (2008) Finite element modelling for piled raft foundation in sand. In: 11th East Asia-Pacific conference on structural engineering and construction (EASEC-11) Building Sustainable Environment, Nov 19-21, 2008, Taipei, Taiwan, pp 1-8

16. Sandeep R, Balakumar S (2010) Effect of piles on response of raft foundations. In: Indian Geotechnical Conference, Geotrends December 16-18, 2010 IGS Mumbai Chapter \& IIT Bombay

17. Gebregziabher HF, Katzenbach R (2012) Parametric studies on application of CPRF on semi soft stratified soils. GeoCongress, ASCE, pp 125-134

18. El-Kadi O, EL-Nahhas FM, El-Mossallamy YM (2012) Performance of pied raft systems. Master thesis, Ain shams university, Egypt

19. Elarabi H, Mahmoud MA (2012) Modelling of piled raft foundation on soft clay. The International Conference for Postgraduate Studies and Scientific Research, Sudan

20. Hemada A (2014) Use of creep piles to control settlement of raft foundation on soft clay-case study. In: 8th Alexandria international conference on structural and geotechnical engineering, Egypt, GT 89

21. Elwakil AZ, Azzam W (2016) Experimental and numerical study of piled raft system. AEJ-Alexandria Eng J 55:547-560

22. Mil S, Singh B (2018) Behavior of large piled-raft foundation on clay soil. Ocean Eng 149:205-216

23. Patil JD, Vasanvala SA, Solanki CH (2013) A study on piled raft foundation: state of art". Int J Eng Res Technol (IJERT) 2(8):1464-1470

24. Katzenbach R, Arslan U, Moormann C, Reul O (1998) Piled raft foundation interaction between piles and raft. Darmstadt Geotech Darmstadt Univ Technol 4:279-296

25. Katzenbach R, Arslan U, Moormann C (2000) Piled raft foundation projects in Germany. In: Hemsley JA (ed) Design application of raft foundation. Thomas Telford, London, pp 323-339

26. Sommer H, Katzenbach R (1991) Last-Verformungsverhalten des Messeturms Frankfurt/Main. Vorträge der Baugrundtagung, Karlsruhe, pp 371-380 (in German)

27. Schetelig K, Franke E (1985) In-situ stresses in over-consolidated clays relative to depth. In: Proceedings of the 11th ICSMFE, San Francisco 2:647-652

28. Davis RO, Slevdaurai A (1996) Elasticity and geomechanics. Cambridge University, Cambridge

29. Davis RO, Slevdaurai A (2002) Plasticity and geomechanics. Cambridge University, Cambridge

30. Brinkreve R, Swolf W (2007) Plaxis 3D foundation, finite element code for soil and rock analyses. User's manual. Plaxis, Deft

31. El-Mossallamy YM (2004) The interactive process between field monitoring and numerical analyses by the deployment of piled raft foundation. Geotechnical innovation, international symposium, university of Stuttgart

32. Meyerhof GG (1976) Bearing capacity and settlement of pile foundations. J Geotech Eng Div 102(3):195-228 